\title{
Styrd skolintegration för ökad likvärdighet och social sammanhållning
}

\author{
Stefan Lund \\ Stockholms universitet
}

\begin{abstract}
Artikeln fokuserar på ett område som är relativt unikt i ett svenskt forskningssammanhang. Nämligen hur en kommun genom skolomorganisation och bussning av elever i sin F-6 verksamhet söker hantera skolsegregationens negativa effekter. Artikelns syfte är att beskriva och analysera hur ett narrativ för styrd skolintegration artikuleras av kommunala policyaktörer samt redogöra för hur detta narrativ understödjs av kontextuella omständigheter och processer. Studien bygger på intervjuer med kommunpolitiker, tjänstemän, rektorer, samt en av de föräldrar som var drivande i protesterna mot omorganisationen. Resultaten visar att policyaktörernas argumentation vilar mot ett förenande narrativ som förankras i skollagen, enhetsskolans ambition om en "skola för alla", kollegialt lärande och en grundmurad tilltro till att social interaktion mellan olika grupper av elever reducerar fördomar och överskrider sociala och etniska gränser. Analysen visar vidare att detta narrativ samvarierar med kontextuella omständigheter och processer: (i) strukturella villkor (avstånd mellan skolor, befintliga skolbyggnader, få friskolor), (ii) historiskt och kulturellt förenande meningssystem (lång vana av och behov av arbetskraftsinvandring samt att olikhet generellt uppfattas som berikande för utvecklingen av kulturell och ekonomisk tillväxt) samt (iii) engagerade policyaktörers förmåga att överskrida meningsskillnader (eniga kommunpolitiker, kontinuerlig och transparant kommunikation internt och externt kring reformprocessen). Genom att binda upp narrativets bärande argument mot en moraliskt motiverad meningsstruktur som förstärks av platsens strukturella och kulturella förutsättningar skapar policyaktörerna legitimitet inom den egna verksamheten och förmår även över tid överskrida lokalsamhällets oro och rädslor.
\end{abstract}




\section{INLEDNING}

Jag är så glad för att jag har fått vara med om det här. Vi gör sådan skillnad för så många barn. Som lärare gjorde man skillnad för sin klass, som rektor för sitt område. $\mathrm{Nu}$ gör vi skillnad för ett samhälle. Det är stort! (Tjänsteman och projektledare vid utbildningsförvaltningen, tidigare rektor på Västerskolan)

Den tjänsteman som uttalar sig i det inledande citatet har varit en av de drivande aktörerna $\mathrm{i}$ processen med att omorganisera en mindre svensk kommuns grundskoleverksamhet i syfte att skapa en integrerad skola. I mina intervjuer med politiker, tjänstemän och rektorer i kommunens centralort framkommer att motiven till att omorganisera skolan grundas i en förvissning om att skolsegregationens effekter innebär att skollagens premisser om demokratisk fostran och likvärdig måluppfyllelse inte kan uppfyllas (SFS 2010:800). Framförallt finns en farhåga om att skol-segregationen bidrar till att försvåra den samhälleliga inkorporeringen och skolframgången för elever från "lågstatusgrupper". Det vill säga barn till arbetslösa föräldrar med låg utbildningsnivå och/eller som avviker från majoritetssamhället på grund av sin etnicitet och religion (jfr Alba \& Holdaway, 2013). Mot denna bakgrund ger kommunfullmäktige uppdrag om att tillsätta en utredning som skall föreslå en ny organisationsmodell för kommunens grundskoleverksamhet. Utredningen $^{1}$ visar att det finns stora skillnader i måluppfyllelse mellan centralortens tre F-6 skolor samt att riktade ekonomiska och pedagogiska resurser mot den skola som haft lägst måluppfyllelse och en hög andel elever med utländsk bakgrund ( $<70 \%$ ) inte gett något resultat. Satsningar på kompetensutveckling för lärare, utveckling av digitalt stöd i undervisningen, utveckling av extra studiestöd, lovskolor, läxhjälp, extra undervisning i svenska för elever med annat modersmål och karriärtjänster har inte bidragit till en ökad likvärdighet. Med utredningen som grund fattar en enhällig kommunfullmäktige beslut om att skolverksamheten i centralorten ska omorganiseras med start 2017. De tidigare tre F-6 skolorna blir till två F-3 skolor och en 4-6 skola. Gränser mellan olika anvisningsskolor ritas om och samtliga elever erbjuds bussning till sina nya skolor.

Artikeln baseras på ett studieobjekt som är relativt unikt $\mathrm{i}$ ett svenskt forskningssammanhang, nämligen hur lokala policyaktörer argumenterar för vikten och betydelsen av att $\mathrm{i}$ handling motverka skolsegregation och aktivt styra mot skolintegration. Artikelns syfte är att beskriva och analysera hur ett narrativ för styrd skolintegration artikuleras av kommunala policyaktörer (politiker, tjänstemän och rektorer) samt redogöra för hur detta narrativ understödjs av kontextuella omständigheter och processer.

Genom att besvara detta syfte är min förhoppning att artikeln ska bidra med erfarenheter och kunskaper om hur kommunal styrning mot en 
integrerad grundskola har gått till i praktiken. Inte minst är detta av intresse i tider då skolsegregation i förhållande till likvärdig måluppfyllelse, social sammanhållning och samhällelig inkorporering sätts under utbildningspolitisk granskning och debatt (OECD 2015; SOU 2020:28). Erfarenheter, kunskaper och tolkningar som kan ge alternativ till en i många stycken debatterande (se Dagens Nyheter, 2018; 2020; Svenska Dagbladet, 2018), men i praktiken till synes handfallen utbildningspolitisk agenda.

\section{TIDIGARE FORSKNING}

I syfte att ge en bakgrund till den bakomliggande anledningen till kommunens ställningstagande om att aktivt verka för styrd skolintegration kommer jag i det följande redovisa vad som inom pedagogisk och samhällsvetenskaplig forskning framkommit som drivande omständigheter och utfall av en segregerad skola. I ett nästa steg redovisas forskning kring olika former av styrd skolintegration.

Inom den pedagogiska och samhällsvetenskapliga forskningen uppfattas skolsegregation generellt som ett samhälleligt och demokratiskt problem. Framförallt handlar kritiken om att socioekonomiskt och etniskt homogena skolkulturer förhindrar grundskolans möjligheter att uppfylla den svenska skollagens övergripande målsättningar om att verka för att alla barn ska ges likvärdiga möjligheter till kunskapsutveckling, motverka fördomar och intolerans samt utveckla elevernas förståelse för samhällets kulturella mångfald (se Dahlstedt, 2018; Lund, 2015; Bunar \& Sernhede, 2013). Forskningen visar att utbildningssystemets reproducerande effekter har tilltagit alltsedan introduktionen av skolvalfrihets- och friskolereformerna under mitten av 1990-talet (Dovemark \& Beach, 2016). Hansen och Gustavsson (2016) har i sin longitudinella studie visar att den sociala bostadssegregationen varit konstant under ett drygt decennium, men att skolsegregationen vad beträffar elevers skolframgång och utländsk bakgrund har tilltagit. Vidare framgår att bostadssegregation, totala antalet barn i upptagsområdet, skolvalfrihet och andelen friskolor tillsammans med mängden elever med utländsk bakgrund förstärker skolsegregationen och minskar andelen skolor med etniskt mixade elevgrupper (Malmberg \& Andersson, 2020).

I ett utbildningssystem med hög grad av skolvalfrihet blir föräldrarnas agerande en drivande faktor för skolsegregationen (Osman \& Månsson, 2015). Svenska och internationella studier visar att en majoritet av föräldrar visar stort stöd för en likvärdig och mångkulturell skola där olikheter möts och interagerar (Roda \& Stuart Wells, 2013; Mella \& Palm, 2007; Orfield \& Lee, 2006). Samtidigt tenderar föräldrar att välja skolor där de andra barnen och deras familjer liknar deras egen familj (Roda \& Stuart Wells, 2013; Bifulco m.fl., 2009). Forskningen visar att de flesta skoldistrikt/kommuner inte alls hanterar betydelsen av etnicitet som en aspekt $\mathrm{i}$ föräldrars och barns 
skolvalsprocesser. I ett sådant system lämnas föräldrarna ansvariga att hantera de dominerande ideologier och diskurser som definierar "mångkulturella" skolor som dåliga och de "svenska" skolorna som bra (Voyer, 2018; Roda \& Stuart Wells, 2013). Dessa ideologier och diskurser driver skolsegregationen genom att de mest skolframgångs rika och/eller socioekonomiskt resursstarka eleverna med utländsk och svensk bakgrund lämnar sina anvisningsskolor i utanförskapsområden. Istället väljer de skolor med högre andel etniskt svenska elever och bättre måluppfyllelse (Dovemark \& Holm, 2017; Ambrose, 2016; Kallstenius, 2010). Forskningen visar vidare att det inte är avsaknad av information, skolrykten eller betyg som hindrar elever från etniska minoritetsgrupper att genomföra sin grundskoleutbildning vid skolor med hög måluppfyllelse och där majoriteten av eleverna har "svensk" bakgrund. Istället är det rädslor för att inte passa in i den "svenskdominerade" skolkulturen och brist på erkännande som gör att de stannar vid, eller återvänder till sina skolor i utanförskapsområdena (Ambrose, 2020; Holm \& Dovemark, 2020). Sammantaget skapar detta en mångfaldig skolsegregation. Social bakgrund, etnicitet och elevers studieresultat samvarierar och förstärks i ett segregerat skolsystem.

Dessa processer genererar och förstärker i sin tur symboliska gränser mellan "vi" och "de andra". De invandrartäta skolornas "vi" och de svensktäta skolornas "vi" ställs emot varandra. Skolor med studiemotiverade elever och där majoriteten har svenska som modersmål uppfattas inte som segregerade skolor eftersom dessa i högre grad uppfyller och representerar de mål som utbildningssystemet eftersträvar. Dessa skolor tenderar också att attrahera resursstarka elever (utbildningskapital och studiemotivation) med utländsk bakgrund (Kallstenius, 2010; Bunar \& Ambrose, 2016). Med andra ord framställs dessa som välfungerande skolor med hög måluppfyllelse där barn och ungdomar ges likvärdiga möjligheter till kunskapsutveckling. Det motsatta gäller för skolor belägna i områden där majoriteten av befolkningen har utländsk bakgrund och där måluppfyllelsen är låg. Dessa mångkulturella skolor med en elevsammansättning av få etniskt svenska barn men med en stor variation av barn från olika minoritetsgrupper framställs som segregerade. Bland andra har Nilsson (2015) och Ambrose (2016) visat att dessa skolor dras in i en spiral av tilltagande exkludering. När skolorna inte förmår att kompensera för de ojämlika villkor som hem- och boendemiljön erbjuder så väljer elever med betydande ekonomiska och kulturella resurser att söka sig till skolor utanför det segregerade bostadsområdet. Homogeniseringen i dessa skolor är därmed inte enbart baserad på etnicitet utan även av att socioekonomiskt resursfattiga elever blir kvar när de socioekonomiskt resursstarka eleverna lämnar. Dessa elevgrupper blir till ett stigmatiserat "de andra", istället för att höra till ett inkluderande "vi", och som i forskningen och i den offentliga debatten framställs som ett hot mot utbildningssystemets förmåga att erbjuda barn och ungdomar likvärdiga 
möjligheter till kunskapsutveckling och ett aktivt medborgarskap (Lund, 2020).

Sammanfattningsvis kan sägas att villkoren inför omorganisationen i den aktuella kommunen i hög grad kan likställas med vad den tidigare forskningen visat. Nämligen hur bostadssegregation och skolsegregation samspelar med bristande likvärdighet i måluppfyllelse mellan olika kommunala skolor, att segregerade skolor definieras som frånvaro av svenska barn och "alltför" hög ansamling av elever med utländsk bakgrund och att eleverna i lägre grad än övriga skolor når utbildningsmålen.

\section{Styrd skolintegration}

Forskningen om styrd skolintegration har en lång historia i framförallt USA där afroamerikanska och latinamerikanska elever bussats till skolor med en majoritet av "vita" elever (exv. Danns, 2011) i syfte om att skapa etniskt mixade elevgrupper. Den bärande idén bakom spridning av minoritetselever till skolor där elevsammansättningen domineras av "vita" elever och med högre skolresultat är förväntan om positiva kamrateffekter (Warikko, 2011; Delmont, 2016). Huruvida detta har fungerat i praktiken är ett omstritt fenomen. Billings m.fl. (2013) har genom registerdataanalys av drygt 50000 elever visat att segregerade skolor där majoriteten av eleverna tillhör minoritetsgrupper bidrar till generellt försämrade skolresultat samt att aktivt styra skolors elevsammansättning kan vara den bästa vägen för att skapa ett mer jämlikt utbildningssystem. Brummet (2014) som studerat 200 skolnedläggningar i Michigan har kommit fram till att elever från lågpresterande skolor får en förbättrad skolframgång i sina nya skolor. Samtidigt menar andra forskare att styrd skolintegration ofta får som följd att den vita medelklassen byter bostadsort och/eller genom aktiva skolval flyttar sina barn till andra skolor (Coleman m.fl, 1975). Med andra ord kan policyer för styrd skolintegration förskjuta och bidra till att skolsegregationen blir än mer omfattande.

Liknande resultat av styrd skolintegration har Kornvall och Bender (2018) funnit i sin studie av Nyköpings kommun och dess försök att bryta skolsegregationen genom skolnedläggning och sammanslagning av befintliga högstadieskolor genom nybyggnation av en kommunal högstadieskola för alla ungdomar. Deras studie visar dock att i samband med nybyggnationen väljer svenska välutbildade föräldrar att flytta sina barn till friskolor. Skolsegregationen som innan nybyggnationen fanns mellan kommunala skolor tar alltså en annan form, mellan den nybyggda kommunala skolan och friskolor (jfr Roda \& Stuart Wells, 2013). En annan form av styrd skolintegration undersöks i Wigerfelts (2010) studie av en skola i Malmö. Hon har beskrivit och analyserat hur elever i ett utanförskapsområde genom kommunala beslut flyttats till en svenskdominerad högstadieskola i syfte att motverka skolsegregation och skapa en socioekonomiskt och etniskt integrerad skol- 
verksamhet. Wigerfelt (2010) visar att när elever med utländsk bakgrund flyttas från en skola i ett utanförskapsområde till en "svenskdominerad" skola ökar måluppfyllelsen hos dessa elever. Eleverna själva och dess lärare förklarar att denna förändring $i$ huvudsak skett på grund av att de fått fler studiemotiverade vänner (jfr Lund \& Lund, 2016). I en nyligen utgiven rapport visar Jämte m.fl. (2021) att den aktuella kommunen inte ser några andra alternativ än att lägga ner den mest segregerade och underpresterande Vivallaskolan och sprida ut dessa elever på fyra andra kommunala skolor. Resultaten av den styrda skolintegrationen pekar på att måluppfyllelsen för de befintliga eleverna på mottagande skolorna inte förändras (se LarssonTaghizadeh, 2020) samt en svagt negativ måluppfyllelse för eleverna från Vivallaskolan (på grund av lågt antal elever är analyserna dock inte signifikanta). Analysen pekar vidare på att det finns stora skillnader mellan de fyra mottagande skolorna vad beträffar måluppfyllelse och social samvaro mellan olika etniska grupper av elever.

Sammanfattningsvis har forskningsgenomgången visat hur tidigare studier företrädesvis genomförts i storstadsregioner och i medelstora städer. I samtliga fall har högstadie- och gymnasieskolan varit i fokus. Föreliggande studie skiljer sig från den tidigare forskningen inom området då den undersöker hur en mindre kommun söker utveckla likvärdigheten och den sociala sammanhållningen mellan olika elevgrupper i låg- och mellanstadiet genom att aktivt styra skolornas socioekonomiska och etniska elevsammansättning.

\section{METOD}

I forskningsgenomgången har jag visat att kommunal styrning mot integrerade skolor i en svensk kontext är knapphändigt analyserad. I hög grad beror detta på att de kommunala initiativen med några undantag har varit få, och att det därför finns begränsad kunskap om dessa policyprocessers bakomliggande motiv och genomförande. I artikeln kommer jag att använda mig av begreppet policyaktörer i syfte att skapa en vid förståelse för hur utbildningspolicy produceras, legitimeras och genomförs. Utgångspunkten för detta begrepp är tagen i Ozgas (2000) tolkning om att "görandet" av policy inte är en linjär process, utan skapas i en pågående förhandling där argument för eller emot en omorganisation av kommunens grundskoleutbildning reser med hjälp av flera olika aktörer på olika nivåer i samhället. Att öppna upp och studera förändringsprocesser på detta sätt skapar en ökad möjlighet till nyanserade tolkningar av pågående policyprocessers dynamik (Ozga 2000).

Datamaterialet i denna artikel består av intervjuer med tre politiker, två tjänstemän (varar den ena intervjuades vid två tillfällen), tre rektorer, två biträdande rektorer och en förälder. Intervjuerna med politiker, tjänstemän och skolledning genomfördes under en "fältstudievecka", planerad av mig 
och en tjänsteman på kommunen, under oktober 2019. Samtliga av de intervjuade individerna, kan förstås som "nyckelpersoner" för initiering och genomförande av den styrda skolintegrationen i kommunen. Samtliga har under tiden före och efter omorganisationen av centralortens skolor, på olika sätt, haft del $\mathrm{i}$ arbetet med att aktivt verka för integrerade skolor. Valet att intervjua dessa individer beror alltså på deras aktiva medverkan i omorganisationen samt att det var i centralorten som diskussionen om hur skolsegregationen och skolans bristande likvärdighet startade och diskuterades över tid.

Intervjuerna med politiker och tjänstemän genomfördes i "kommunhuset" och rektorsintervjuerna på respektive skola. Samtliga var av semistrukturerad karaktär (Kvale, 1997) och innehöll följande temaområden: bakomliggande motiv till omorganisation, samhälle och kultur, process och genomförande, pedagogiska arbetssätt i en mångkulturell skola - måluppfyllelse och sociala relationer, samt utfall och erfarenheter. Intervjuerna som spelades in varade mellan 1-1 1/2 timme och har skrivits ut. I samband med att jag påbörjade mina tolkningar och analyser av datamaterialet insåg jag att en specifik förälder ofta förekom i intervjuerna. Föräldern beskrevs vara initiativtagare och ledare för de föräldraprotester som tog form i samband med beslutet $i$ kommunfullmäktige. Jag valde därför att kontakta denne och genomförde en inspelad telefonintervju som varade drygt en timme. Även denna intervju har skrivits ut.

En annan ort i kommunen berördes också av beslutet 2017 i kommunfullmäktige. I denna ort innebar omorganisationen att två F-6 skolor blev en F-3 och en 4-6 skola. Även här genomförde jag intervjuer med skolledarna. Den samlade bilden är att omorganisationen i detta samhälle handlade om att "göra lika" $i$ hela kommunen samt att samla lärarresurser och få behöriga lärare i samtliga ämnen på respektive åldersstadium. Här fanns inte motsvarande exempel på skolsegregation och bristande likvärdighet mellan skolor som var fallet $i$ centralorten och lärare och rektorer menar att omorganisationen skedde relativt friktionsfritt i förhållande till skolpersonal och föräldrar. Dessa intervjuer har inte inkluderats i resultatredovisningen.

Samtliga intervjupersoner har informerats om att ljudupptagning räknas som personuppgifter enligt EU:s dataskyddsförordning 2016/679 (GDPR). Vidare har de fått kunskap om att intervjuerna kommer att spelas in men att denna information inte kommer att kunna kopplas till intervjupersonen eftersom forskarna i projektet rensar informationen från uppgifter som kan kopplas samman med individen (till exempel namn på personer och platser) samt att Stockholms universitet är personuppgiftsansvarig för behandlingen av personuppgifter. Slutligen har intervjupersonerna informerats om att projektet följer principer om etik i forskningen och datalagring som finns fastställda i den gällande lagstiftningen och Vetenskapsrådets rekommendationer, samt att svaren kommer att förvaras och behandlas så att inte obehöriga kan 
ta del av dem. Inga register över de medverkande personerna kommer att upprättas och namn på kommuner, skolor och de medverkande personerna kommer inte att anges i databanken eller vid publikationer. Samtliga intervjupersoner har samtyckt till medverkan i studien.

\section{Tolkning och analys}

Mina tolkningar och analyser av det empiriska materialet i denna studie är relaterat till Jeffrey C. Alexanders (2006) civilsfärsteori. Alexander menar att inkorporering till demokratiska samhällen tar form inom en civil sfär som: "...defines itself in terms of solidarity, the brotherly and sisterly feeling of being connected with every other person in the collectivity" (Alexander \& Tognato, 2018, s. 17). Inkluderingen i, och gränserna för att inkorporeras består sålunda av kulturellt bundna normer och värden som kontinuerligt förhandlas och reflekteras över. Denna förhandling är riktad mot vad Alexander (2013, s. 536) beskriver som "the affective and moral meaning of 'us"'. I mina kommande tolkningar kommer jag att visa hur de drivande policyaktörerna, genom införandet av integrerade skolor, vill förändra den rådande kulturella meningsstruktur som legitimerar förståelsen för skolans roll i samhället och för individen (barn och föräldrar). I deras tolkning ska skola och utbildning inte genom sin organisation verka för tilltagande skolsegregation, ökad homogenisering och separation av majoritets- och minoritetsgrupper. Snarast uppfattar de skola och utbildning vara en central kraft i vad som ska utveckla och hålla samhället samman. Skola och utbildning blir i ett sådant sammanhang till en med Alexanders och Tognatos (2018, s. 10) ord, "interstitial institution", som har kapacitet att mediera civila värden och solidaritet för den andre (jfr Izquierdo \& Minguez, 2003). Skola och utbildning är alltså i deras tolkning en vital kraft för skapandet av ett kollektivt representerat och inkluderande "vi". I sina empiriska studier av civilfären visar Alexander (2006) hur den struktureras genom binära koder som specificerar vilka civila värden, övertygelser och identiteter som är värdiga att inkorporeras och vilka som inte är det. Han menar vidare att känslor av tillhörighet styrs genom mening och emotioner, vilket innebär att civilsfärens "vi" ständigt kan omförhandlas. Sådana symboliska gränser kan förändras och bli mer öppna för en pluralism av civila värden, uppfattningar och identiteter. Det omvända är också möjlig, en inskränkning av civila värden, uppfattningar och identiteter. Oberoende av utfall visar teorin på att förändring är möjlig. För att förändring ska ske pekar Alexander (2006) på vikten av att länka samman de bakomliggande argumenten för social förändring med moraliskt gemensamma narrativ $i$ vilka befolkningen kan acceptera och känna igen sig. Förutom dessa moraliskt representativa narrativ krävs framträdanden och handling (Alexander, 2011). För att skapa legitima skäl för förändring behöver samhällsmedlemmar intellektuellt och emotionellt förstå och känna att en omorganisation mot integrerade skolor inte bara är nödvändig utan också 
moraliskt rättfärdig. Det är endast då majoriteten känner och tror på att argumenten är logiska och rättvisa som politisk förändring kan ta form.

Analysen av mitt material fokuserar därav på policyaktörernas berättelser om bakgrunden till och argumenten för att aktivt omorganisera delar av sin grundskoleverksamhet. En begränsning i denna studie är att intervjuerna handlar om policyaktörernas retrospektiva minnen kring den förberedande processen, beslutet och genomförandet av styrd skolintegration. Deras berättelser bygger på subjektiva upplevelser och minneskonstruktioner av vad som skett. Minnen som kan ha påverkats av andra policyaktörers berättelser, men även av samhälleliga narrativ kring skolsegregation och skolintegration. Dessa berättelser ger oss alltså inte information om de samhälleligt förankrade narrativ som artikuleras kring skolans roll för likvärdighet i måluppfyllelse och social sammanhålnning. Istället ska policyaktörernas utsagor och berättelser förstås som deras kreativa strävanden av att tolka, förstå och förklara bakgrunden och genomförandet av omorganisationen av kommunens grundskolor (Jessee, 2018). Detta antagande bygger vidare på att individuella minnen är nära kopplade till den betydelse en viss händelse eller ett händelseförlopp har för intervjupersonerna. Av intervjuerna framgår att policyaktörerna har varit djupt engagerade i framtagande och genomförandet av omorganisationen. Deras berättelser om händelseförloppen är också i hög grad överlappande.

Narrativ analys handlar om att lyfta fram berättarens erfarenheter och tolka hur berättelsen skapar (ny) mening i ett vidare sammanhang (Riessman, 2008). I artikelns teoretiska perspektiv ska policyaktörernas berättelser därmed inte förstås som individuella betraktelser, utan vara länkade till kollektivt delade narrativ som tydliggör olika typer av meningsstrukturer om exempelvis det mångkulturella samhället och utbildningens samhälleliga funktion $\mathrm{i}$ förhållande till elevers likvärdiga möjligheter till måluppfyllelse och samhälleliga inkorporering. Precis som jag diskuterat tidigare är dessa dominerande narrativ inte deterministiska utan snarast utsatta för kontinuerlig prövning och omprövning. Kulturellt definierade meningsstrukturer, menar Alexander (2006), vägleder snarare än definierar handling. Mot denna bakgrund har jag fokuserat på de gemensamma teman som policyaktörerna tar upp, samtidigt som jag har tolkat och analyserat narrativet som omorganisationen vilar på i relation till artikelns teoretiska utgångspunkter.

\section{RESULTAT}

Centralortens tre låg- och mellanstadieskolor ligger i stadsdelar med helt olika arkitektoniska beskaffenhet, vilket enligt de olika policyaktörerna har haft stor betydelse för att en tilltagande skolsegregation har tagit form. En av de föräldrar som aktivt protesterade mot omorganisationen och var initiativ- 
tagare till "skolupproret", en Facebook grupp med cirka 1200 medlemmar, menar att:

... den här segregationen på skolorna det är inget nytt. Den har pågått sedan 70-talet i princip. Vi har ju alltid haft arbetskraftsinvandring och det har blivit så att många med utländsk bakgrund har hamnat på Österområdet. Det har ju kommit människor från Grekland och Jugoslavien och andra länder. (...) Det (skolsegregationen) ${ }^{2}$ beror ju på en sak i grund och botten. Det är kommunens fel så att säga. För alla nyanlända som kommer de har ju blivit bosatta uppe på det område som heter "Öster". Och då var ju Österskolan den skola som var närmast.

Österskolan ligger i en stadsdel som uppfördes under åren 1969-1972 och består i huvudsak av hyreslägenheter och med inslag av ett fåtal bostadsrätter. Området har tydliga kopplingar till miljonprogrammens arkitektur och det har precis som i liknande områden i större städer förekommit stenkastning mot polis och bilbränder. Området har historiskt befolkats av tidigare arbetskraftsinvandrande familjer och flyktingar från kriget i forna Jugoslavien samt under senare år framförallt av familjer med flyktingstatus. Skolan är även anvisningsskola till barn boende på landsbygden.

I Norrskolans upptagningsområde finns en blandning av villabebyggelse och hyreslägenheter. Området planerades under 1950-talet av arkitekter från det Kooperativa förbundet och de flesta villor är "typhus" från KF:s katalog. Arkivmaterial visar att de som sökt bygglov i området i hög utsträckning varit anställda i en av samhällets största industrier. Under 1990-talet tillkom bebyggelse i form av hyreslägenheter. Rektorn, som arbetat under en längre tid på Norrskolan, beskriver bostadsområdet och elevunderlaget såhär:

... det var lite trasigt och tungt, vi hade mycket kontakt med socialen och så... det var inte bara barn med utländsk bakgrund utan precis lika många med svenskfödd bakgrund. (...) dåligt med pengar, jobb och kanske till och med arbetslösa. Här fanns och finns alltid lediga lägenheter. Folk flyttar in och ut lite så. (...) när jag kom hit för 10-11 år sedan så fanns det en föräldraförening, och det sista möte vi hade innan jag upplöste den så var vi 4-5 personal och 2 föräldrar. Det var liksom ingen mening.

I Västerskolan är föräldraengagemanget ett helt annat. En intervjuperson som länge varit verksam som rektor vid skolan menar att det fanns och finns ett starkt föräldraengagemang och en etablerad studietradition i skolan. Vidare har det etablerats en lång tradition om att tätortens rektorer träffas med jämna mellanrum. Vid dessa möten tog den dåvarande rektorn ofta upp att det framkommit klagomål från föräldrarna: "Det var mycket ifrågasättande. Fick de inte de resurser som de ville på en gång så protesterade de. (...) Sådana som är vana att få någonting gjort och att det händer”. Området byggdes 
under 1970-talet och består till största delen av villor med några få inslag av hyreshus. Den biträdande rektorn vid Västerskolan sammanfattar skolsegregationen före omorganisationen såhär:

Jag har ju varit i alla områdena och det är helt olika problematiker. Öster som var en skola med väldigt få svensktalande barn. Norr en skola med social problematik bland de svenskfödda barnen och många hyreshus och så Väster som har sina medelklassföräldrar boende i villor och som vill vara med och påverka. Så alla skolor har sina utmaningar.

I mina intervjuer framkommer alltså, att det som i ett utifrånperspektiv ser ut att vara en reaktion på flyktingkrisen under framförallt 2015, i själva verket handlar om en långvarig process av ökad skolsegregation och minskad likvärdighet i måluppfyllelse mellan skolor. En av barn- och ungdomsnämndens (BUN) ledamöter säger:

De här diskussionerna har ju varit jätte, jättelänge. Jag pratade med en som satt i skolnämnden tidigare och man talade om detta redan på 1990-talet. Men man kom inte till skott då. Eftersom man inte vågade göra något för att få en bättre fördelning av barnen i tätorten (...).

Inte desto mindre menar samtliga intervjuade policyaktörer att bilden av skolsegregationen i tätorten var allmänt känd av såväl politiker, tjänstemän, skolpersonal och befolkningen $i$ allmänhet.

\section{Policyaktörer och deras argument}

Enligt policyaktörerna har de grundläggande argumenten vuxit fram under en process, där politiker, tjänstemän och framförallt rektorer försökt finna lösningar för att förbättra skolans likvärdighet och den sociala sammanhållningen bland kommunens medborgare:

Det första och största argumentet handlade om segregationen. Det kom andra argument längre fram, men ursprungstanken var att det såg galet ut. (...) Det var snett, och vi diskuterade, hur kan man jämna ut detta? Där var vi väldigt tidigt ute med att vi inte gör detta för våra skolors skull utan det var för kommunens skull. Det var faktiskt så, det vill jag nog påstå. Kritiker kan nog påstå att vi gjorde det för vår egen skull, men det var faktiskt samhällsnyttan, att centralorten XX skulle må bra av detta (Rektor, Norrskolan).

Samtliga av de intervjuade rektorerna och den tjänsteman vilken tidigare arbetade som rektor på Västerskolan menar att initiativet till omorganisationen startade i den ovan omtalade rektorsgruppen. Diskussionerna började enligt rektorerna ta fart på allvar 2011, och då handlade det främst 
om relationen mellan likvärdiga förutsättningar till måluppfyllelse mellan olika skolor samt bostads- och skolsegregation. Uppfattningen är att rektorernas samlade röst gjorde att BUNs ledamöter började lyssna och förstå omfattningen av skolorganisationens stigmatiserande effekter:

Det är så viktigt att jobba för att undvika stigmatisering. Så att inte vissa får och andra inte. För alla vill passa in. Det är det som man kämpar för hela livet. (...) Så jag tror att de litade på att vi alla tre rektorer ville detta. Inte bara den skola som hade mest problem. Vi tryckte på det hårt i nämnden. Vi kommer aldrig att bli en bättre skolkommun om vi inte gör någonting (Tjänsteman och projektledare, tidigare rektor på Västerskolan).

Diskussionerna handlade om hur skolsegregationen skapade problem på olika nivåer i samhället, vilket fördes vidare till tjänstemän och politiker. Mot denna bakgrund är min tolkning att det skapades en samlande problembeskrivning om att samverkande effekter av skolsegregationen påverkade såväl den sociala interaktionen mellan olika grupper i samhället som likvärdig kunskapsutveckling bland kommunens barn och unga. Denna problembeskrivning av skolsegregationens negativa effekter kom att utgöra grunden för de argument som pekade på vikten av att aktivt verka för en integrerad skola:

i. $\quad$ barnen med utländsk bakgrund får inte en naturlig tillgång till det svenska språket och därmed svårigheter med måluppfyllelse och att anpassas till det svenska samhället:

Du kan aldrig klara dig i ett annat land där du upplever att landets språk är ett främmande språk. Det blir ju helt omöjligt. Det är ju därför folk sitter isolerade och har problem. Om du inte tar tag $\mathrm{i}$ detta med denna generationen barn så (...) (Politiker).

ii. till synes symboliskt och socialt cementerade gränser mellan olika bostadsområden skapar låg rörlighet och mellan olika etniska och sociala grupper av barn och ungdomar (jfr Lamont \& Molnár, 2002):

Vi har ju tänkt hela tiden att det är mycket bättre att de får träffas tidigt. För får du kompisar tidigt så underlättar det när de kommer till 7an. Några av barnen som kom från Väster sa när de kom till Österskolan att 'jag har ju aldrig varit i den här stadsdelen'. (...) För dit åkte man inte. Och vise versa (Tjänsteman och projektledare, tidigare rektor Västerskolan).

iii. det sociala kittet i samhället splittras upp och skapar symboliska och sociala gränser mellan "vi" och "dem": "En sak som jag tänker är ju 
möten i samhället. Hallå! Dig känner jag! Att ett så här litet samhälle inte ska vara vi och dem på samma sätt som man kan uppleva idag (Biträdande rektor, Österskolan).

Som vi kan utläsa av ovanstående argument finns en grundmurad tanke om att bostadssegregationen och skolsegregationen symboliskt och socialt delat upp olika befolkningsgrupper, vilket i sin förlängning minskar den sociala sammanhållningen och skapar flera samhällen $i$ ett. Lösningen på denna problematik handlar för policyaktörerna om att tidig intervention (jfr Sjöstrand Öhrfelt, 2019) förbättrar måluppfyllelsen, ökar likvärdigheten, motverkar fördomar samt förbättrar den sociala sammanhållningen mellan olika grupper. Framförallt påtalas att elever med utländsk och svensk bakgrund behöver träffas och etablera relationer redan i grundskolans tidiga stadier. Policyaktörerna ger en bild av att yngre barn lättare skaffar nya vänner och genom att bryta med den etniska skolsegregationen så kommer de okända inte längre upplevas som ett hot:

Ju fler som är mina vänner och ju färre som är dom där (...) Ibland har det med hudfärg att göra och ibland med något annat. Att kategorisera är ju ett sätt att få ordning i sin tillvaro. Men om kategorigränserna går på annat håll, så har vi gjort något bra (Rektor, Österskolan).

Så långt har jag visat hur två huvudsakliga argument ger form åt ett narrativ om betydelsen av en integrerad skola. Nämligen, att socioekonomiskt och etniskt blandade skolor utvecklar den sociala sammanhållningen mellan olika grupper i samhället och att styrd skolintegration förväntas bidra till förbättrad likvärdighet i skolornas måluppfyllelse.

Ett tredje argument som enligt policyaktörerna lyftes in senare under processen handlar om en tilltagande lärarbrist och det kollektiva lärandet:

Sen kom ju det här med att lärarbristen $i$ hela Sverige blev katastrofalt stor, och då blev ju att samla kompetensen väl så viktig som integrationsfrågan. (...) att ha råddat en så här stor grej utan att ha samlat kompetensen det hade ju inte gått. Eftersom det bara finns tre årskurser (4-6) så har vi kompetens i alla ämnen i alla årskurser. (...) Den situationen hade vi ju inte varit i om vi hade fortsatt att vara tre skolor (Rektor, Österskolan).

Istället för att ha tre stycken F-6 skolor och därmed kompetens utspridd på de olika enheterna menar policyaktörerna att en samlad kompetens av behöriga lärare innebär att likvärdigheten och måluppfyllelsen kommer att öka. Centreringen av lärarkompetens baseras på idén om att de behöriga lärarna skall stötta upp de obehöriga lärarna och uppfylla skolans uppgifter om bedömning och betygssättning i alla ämnen. I intervjun med den förälder som var ledande i skolupproret framkommer att han och andra föräldrar 
efterhand insett att just detta med att omorganisationen också var nödvändig för att möta lärarbristen och att elever i samtliga skolor också ska ges likvärdig lärarkompetens i alla ämnen: 'Det handlar ju inte enbart om en likvärdig skola och att klasserna ska vara blandade utan att det handlar ju också om att eleverna ska få jobba tillsammans med behöriga lärare som en väldigt viktig point”. Att detta inte kommunicerades på ett bättre sätt från projekt- och kommunledning var, menar föräldern, en av anledningarna till att föräldrar slöt sig samman för att protestera mot fattat beslut.

Sammanfattningsvis har jag så här långt visat att omorganisationen vilar på tre grundläggande problemområden som det kommit att bli nödvändigt att lösa: skolsegregation och dess upplevt negativa effekter för den sociala sammanhållningen i samhället, brister i likvärdig måluppfyllelse mellan kommunens skolor samt svårigheter med lärarrekrytering och därmed ett behov av att samla lärarresurserna på ett mer systematiskt sätt. Mot denna bakgrund formas ett narrativ som pekar mot att lösningen på dessa problem är en socialt och etniskt integrerad skola. Omorganisationen mötte dock som tidigare nämnts stark kritik från framförallt föräldrar till barn på Västerskolan. I syfte att ge en rikare bild av narrativet för en integrerad skola kommer jag i nästa steg beskriva vad det egentligen var som föräldraprotesterna handlade om.

\section{Föräldraprotester och omorganisation}

Enligt en av de drivande föräldrarna i skolupproret fanns en genuin förståelse bland majoriteten av dessa föräldrar om att skolsegregationen på ett eller annat sätt måste hanteras. Protesterna handlade om andra saker. För det första, och som redan diskuterats ovan, upplevde föräldrarna att det fanns brister i kommunikationen med politiker och tjänstemän. I media och vid möten betonades narrativets tre huvudargumenten från politiken och projektledningen på olika sätt, vilket gjorde att föräldrarna inte kunde avkoda vad detta egentligen handlade om. För det andra handlade protesterna om vikten av att gällande lagstiftning om "närhetsprincipen" inte följdes på grund av omorganisationen:

Många föräldrar har kanske bosatt sig i området för att barnen ska ha nära till skolan. Det kändes som att de glömde bort det mänskliga i det hela. Vi sa ju en annan sak också, att även de nyanlända som hade kommit, de hade ju nära till sin F-6 skola. Det hade ju gångavstånd tidigare och kunde följa sina barn. Så plötsligt skulle sexåringarna som ska börja förskoleklass bussas dit. Istället för att de får $100 \mathrm{~m}$ till skolan så får de $3 \mathrm{~km}$ till skolan (Förälder och ledare av Skolupproret).

Enligt de två tjänstemän som jag intervjuat, fanns det markanta skillnader mellan olika föräldragruppers reaktioner på omorganisationen. De svenska 
medelklassföräldrarna från Västerområdet som kraftfullt argumenterade och protesterade mot förslaget och föräldrar med utländsk bakgrund som kände sig oroliga över vad omorganisationen skulle betyda för deras barn: "De nyanlända var lite oroliga över vad det skulle innebära att inte ha sitt barn nära. Men de protesterade ju inte" (Tjänsteman). Sammantaget handlade "skolupproret" enligt de intervjuade tjänstemännen och rektorerna om osäkerhet och rädslor inför vad som komma skall. Majoriteten av dessa oroliga föräldrar beskrivs av samtliga policyaktörer som sansade och sakliga i sin kritik av omorganisationen. De sökte efter relevanta svar och upplysningar om bakgrunden till projektet och vilka innebörder den skulle få för deras barn, snarare än efter konfrontation och konflikt. Framförallt var det få som i det offentliga uttalade sig negativt om socioekonomiskt och etniskt integrerade skolor. Samtidigt fanns också föräldrar som var mer utåtagerande. Bland annat finns berättelser från policyaktörerna om hur den dåvarande kommunchefen möttes av två maskerade och svartklädda personer i sin trädgård, att föräldrar hotade med att flytta barnen till skolor i intilliggande kommuner samt att föräldrar i skolupprorets Facebook-grupp eller vid fysiska möten kunde gå till personangrepp och komma med rasistiska uttalanden:

Ja det var ju rent... Det var ju folk som kunde skriva såhär: nej fy fan jag vill ju inte att mina barn ska gå ihop med de där djäkla ... ja och så lite fula ord då så att säga. Och det var ju också från andra hållet där vi som var emot den här skolomorganisationen blev kallade för rasister. En hel del fula ord från folk eftersom de ansåg att vi var rasister (Förälder och ledare av Skolupproret).

Vi som föräldrar blev inbjudna till stormöte där man berättade om planen och vad man tänkte och... det var en hätsk stämning. Det var obehagligt! En del skräder inte orden och tänker inte på vad man säger och hur man säger. "Ska mitt barn bli blandat med det folket, den boskapen". Den känslan hade jag när jag gick därifrån (Förälder och Biträdande rektor, Västeskolan).

Som jag har visat har föräldraprotesterna haft olika karaktär. Då samtliga policyaktörer menar att protesterna idag helt har ebbat ut är min tolkning att majoriteten av föräldrarna har haft en grundläggande förståelse för narrativet om betydelsen av en integrerad skola och dess förväntade potential att öka likvärdighet i måluppfyllelse, social sammanhållning samt att optimera befintlig lärarkompetens. Detta har i sin tur marginaliserat föräldramajoritetens argument om att "rycka upp" yngre barn från deras sociala sammanhang, oron över att bussa yngre barn och närhetsprincipens förändrade legitimitet samt tystat minoritetsgruppernas uttalat rasistiska utgångspunkter. Tidigare forskning har också visat att majoriteter av medelklassföräldrar, på en moralisk nivå har en stor förståelse för socialt och 
etniskt mixade skolor (Roda \& Stuart Wells, 2013). Narrativet om den integrerade skolan har i den meningen lyckats smälta samman med en allmänt förankrad uppfattning om den svenska grundskolans huvuduppgifter.

\section{Mot en integrerad skola}

I det följande kommer jag att visa hur narrativet om en integrerad skola understödjs av olika kontextuella omständigheter och processer.

Från rektorer och tjänstemän framkommer att det under processens gång funnits lite olika förslag på hur målsättningen om en mer likvärdig skola skall lösas. En avgörande faktor för den genomförda omorganisationen handlade om att befintliga skolbyggnader skulle kunna utnyttjas: "Det fanns olika alternativ, men det slutade med att det blev två F-3 och en 4-6 skola i 'tätorten'. Det var det mest realistiska när det gäller byggnader, hur stora skolor...". Enligt de intervjuade politikerna var det mest logiskt att göra Österskolan till en 4-6 skola, eftersom dess lokaler var bäst anpassade för att ta emot fler elever. Innan omorganisationen hade samtliga skolor ett underlag på mellan 200-280 elever, och idag har Västerskolan och Norrskolan cirka 200 elever och Österskolan drygt 400 elever. Som längst är avståndet mellan skolorna ca 3 kilometer, vilket policyaktörerna menar möjliggör att elever på ett enkelt sätt kan transporteras mellan olika bostadsområden. Innebörden av detta beslut är att lågstadieelever bussas från Österområdet till Västerskolan och Norrskolan samt att mellanstadieelever från områdena Väster och Norr bussas till Österskolan. Bussningen av elever gäller alltså både majoritets- och minoritetsgrupper i tätorten.

I syfte om att skapa två likvärdiga och jämnstora lågstadieskolor arbetade tjänstemän i kommunen fram nya gränser för skolornas upptagningsområden. Följaktligen delades Österområdet och landsbygden runt tätorten upp mellan Västerskolan och Norrskolan. Indelningen byggde också på insikter kring var olika etniska grupper av familjer bor och tankar om vilka grupper av elever från Österområdet som bäst skulle passa in i respektive skolkultur:

Sen tänkte vi också på att, på Västerskolan så är eleverna ofta väldigt fokuserade och på Norrskolan så har man inte alls haft den fokusen. Inte den studiemotivationen. Då tänkte vi att de syriska barnen, de som verkligen vill ha jobb, de är bättre på att assimilera sig. Framförallt föräldrarna. Och då är det mer krav på Norrskolan tänkte vi. Och sen fick vi den somaliska gruppen som i tätorten ... jag tror inte att det likadant $\mathrm{i}$ hela världen, men här har den stagnerat. De tycker att det är bra att leva som de gör. De behöver inte jobb och de för över det till sina barn som inte vill anstränga sig i skolan och så ... då behöver de komma till Västerskolan för då får de ännu mer draghjälp (Tjänsteman). 
Tjänstemännen betonar att dessa tankar och ambitioner inte var något som de lyfte $i$ offentligheten, men menar samtidigt att de i samband med omorganisationens implementering beaktade alla variabler som de då hade vetskap om. Syftet var inte att peka ut olika etniska grupper, utan att skapa en social och etnisk blandning på respektive skola som på olika sätt skulle passa in i och bidra till att utveckla rådande skolkulturer.

Som jag tidigare beskrivit har forskning visat att kommunala initiativ med liknande ambitioner försvårats genom att företrädesvis medelklassföräldrar väljer att flytta sina elever till andra skolor (jfr Kallstenius, 2010; Kornvall \& Bender, 2018). I den här studerade kommunen finns endast en fristående skola som tar in 10 elever per årskull. De intervjuade tjänstemännen menar att det har funnits intressen från olika huvudmän att etablera friskolor $\mathrm{i}$ kommunen men att intresset från föräldrarna har varit svalt:

De har gått ut med enkäter, men det är inte så många som har vart intresserade tror jag. Man skulle ju kunna ha tänkt sig att eleverna på Västerskolan skulle vilja välja en friskola, men nej, de har sin trygghet där. Och de vet vad de får (Tjänsteman).

Västerskolan framställs som väldigt populär för ortens föräldrar. Den nuvarande rektorn vid skolan säger att hon kontinuerligt får frågor och ansökningar från föräldrar som vill flytta sina barn till skolan. Skolan har ett gott rykte, vilket i detta sammanhang tolkas innebära att friskoleetablering, eller att områdets medelklassföräldrar flyttar sina barn till någon av de omgivande kommunerna inte har skett. Den intervjuade förälder som ledde skolupproret menar att det fanns röster som initialt sade sig ha för avsikt att flytta barnen till andra kommuner, men att han inte känner till någon förälder på Västerområdet som i slutändan valde att flytta sina barn till andra verksamheter.

En första delförklaring är att narrativet om en integrerad skola haft stöd av strukturella omständigheter som tätortens storlek och innevånarantal, befintliga skolbyggnader, avstånd mellan skolor och avsaknaden av reell konkurrens från friskolor.

En andra delförklaring till att narrativet får en bred förankring handlar om bygdens historiska behov av arbetskraftsinvandring, en tillskriven självbild av handlingskraft och starka tilltro till att mångfald är berikande och nödvändigt för kommunens utveckling. Kommunens näringslivsstruktur med stora fabriker, mängder av mindre företag och en stark lokal entreprenörsanda har $i$ ett historiskt perspektiv skapat behov av arbetskraftsinvandring. Det finns alltså en lång tradition av att ta emot arbetskraftsinvandrare, men även flyktingar, framförallt från det forna Jugoslavien. Det har i denna mening funnits ett behov av nya människor i bygden, men också en "vana" av att hantera nyanlända barn inom kommunens skolorganisation. Min tolkning är 
att denna kulturella meningsstruktur sammantaget är grogrund för att narrativet om en integrerad skola får ett brett genomslag:

Vi har alltid varit vana att ta emot människor. För vi har behövt arbetskraftsinvandring. Så att det finns en tradition i tätorten (Tjänsteman).

Vi ska hjälpas åt, fast vi nu är en stor och blandad grupp. Det har varit en framgång här under många år, och om vi vill fortsätta att ha framgång och inte stagnera. Då måste vi tänka om. En företagare som bara tänker på ett sätt, hans företag finns ju inte om 10 år. Han måste in med nytt tänk, och få nya ben att stå på (Tjänsteman, projektledare).

Jag vet att jag (mot politiken) ${ }^{3}$ också tryckte på det här med bygden, [anonymiserad, särskild filosofi och förhållningssätt i bygden]. Här tror man att man klarar det mesta. Och då ska vi banne mig göra det. Och då ska vi göra det med alla som bor där (Tjänsteman, projektledare).

En tredje faktor som tydligt har understött narrativet om förändring mot integrerade skolor handlar om ett kollektivt förankrat aktörskap hos olika nyckelpersoner och en kontinuerlig kommunikation inåt mot verksamheten och utåt mot föräldrar. De tre intervjuade kommunpolitikerna menar att BUN diskuterat frågan om skolsegregationen under lång tid. Alltsedan 2011 då diskussionerna om skolomorganisation intensifierades har dessutom inte nämndens ledamöter bytts ut trots att mandatfördelningen i kommunen skiftat under årens lopp:

Vi tre var överens ... för det kan ju vara så att när man är i opposition så vänder man kappan efter vinden och håller med de som gnäller och ställer sig emot. Men jag jobbade ju lika hårt med detta när jag var i opposition som när jag var ordförande. Det är ju lite olika hur man är som politiker, jag blir ju inte en annan människa för att jag kommer i opposition (...) Det handlar om att ha envetna politiker (Politiker).

Eftersom politikerna i BUN hade jobbat med frågan under en längre tid och var överens om att en förändring var nödvändig fanns en solid grund för att övertyga partikollegorna. Det fanns även en generell förståelse från de övriga nämnderna att frågan om inkorporering av de många nyanlända i kommunen behövde finna sin lösning: "Det var såklart att man behövde tjata och diskutera, men när förslaget kom, var det är ju svårt att ha några motargument mot det. För vad ska vi göra då?” (Politiker). Det fanns dock ett visst motstånd, framförallt inom Centerpartiet och Sverigedemokraterna som var i opposition mot den oheliga allians mellan Socialdemokrater och Moderater då beslutet fattades kring att genomföra omorganisationen. De huvudsakliga 
politiska argumenten mot förslaget var snarlika de som riktats från föräldrarna. Kritikerna menade att det fanns stora risker med att bussa små barn mellan olika områden samt att den förändrade organisationen riskerade att förstöra redan fungerande verksamheter. I BUN var ledamöterna förvissade om att omorganisationen skulle kräva politisk enighet och man arbetade därför hårt för att ena sina partikollegor:

Till sist fick jag med mig en majoritet som tyckte att vi skulle göra det här. Vi var ju till och med överens om att vi från centern skulle rösta olika $\mathrm{i}$ den här frågan. Så jag är säker på att om Sverigedemokraterna hade begärt votering så hade XX röstat nej. Men nu blev det ingen votering så han blev snuvad på det, han fick aldrig någon möjlighet (Politiker).

Just detta med ett enhälligt nämndbeslut menar politikerna var väsentligt inför genomförande och implementering av en integrerande skola. Detta innebär också att man kan arbeta långsiktigt och ingen av de intervjuade politikerna menar att beslutet var felaktigt eller i behov av justering. Tvärt om planeras för en utvidgning av projektet till att beröra andra orter $i$ kommunen samt att verka för en integrerad förskola: "Och är det någon diskussion som nu pågår så är att det att samma sak ska göras med förskolorna också” (Politiker).

Även från tjänstemanna- och rektorshåll lyfts detta med enighet och politiskt mod upp som en viktig faktor för att omorganisationen kunde genomföras. Tjänstemännen menar också att det var av stor vikt att så långt möjligt hålla processen transparent både ut mot föräldrarna och inåt mot kollegiet: "Så vi har ju haft den här kommunikationen med våra medborgare, men vi har också haft det med våra medarbetare. Där det ju fanns de som verkligen var med på idén och trodde stenhårt på den. Men så fanns det de som inte trodde på den, och de lämnade ju skutan” (Tjänsteman). Just detta med kontinuerlig kommunikation och bemötande av kritiska röster samt ett stort mått av beslutsamhet tolkar jag vara en central framgångsfaktor för att försvara och befästa narrativet om en integrerad skola.

Ytterligare en viktig aspekt i detta avseende handlar om tillsättningen av projektledare (tidigare rektor vid Västerskolan, där föräldraprotesterna var som starkast) samt att omsorgsfullt rekrytera nya rektorer med lång erfarenhet och intresse av arbete med utvecklande av mångkulturella skolmiljöer och/ eller professionella erfarenheter av svenska som andraspråk. Tillsammans formade dessa en enad röst och en stark tro på att en integrerad skola var den bästa vägen framåt. I sin tur var detta centralt för att också leda det pedagogiska arbetet med lärarna.

Det fanns även en tydlig strategi för när i tiden politiken skulle fatta beslut kring omorganisationen: "... så gjorde vi det mitt mellan två val. Och det var faktiskt förvaltningschefen som sa att nu är det läge! Man går inte in i ett valår! Det hade vi velat, men det fick vi inte. Vi fick vänta" (Tjänsteman). Dessa 
samverkande omständigheter av samstämmig politik, extern och intern kommunikation, strategisk rekrytering av rektorer och strategi för genomförande kom att understödja narrativet om vikten av en integrerad skola. Narrativets försänkning, från politik till lärarkår kom allt efterhand att vända skolupprorets oro, rädslor och protester till tillit och förtroende. Ett utfall av detta visar sig genom att ledade personer inom skolupproret helt ändrade uppfattning:

Det som var spännande när man väl gick igång med det, var att en av de som var ledande i skolupproret vände (...) De försöker nog inte att lura oss. Vi kan lita på det de säger. (...) Vi har till och med fått lov att citera: "Jag har ändrat ståndpunkt helt. Det här är ju jättebra" (Tjänsteman).

Föräldrarnas förändrade attityd till omorganisationen handlar som jag diskuterat tidigare om att narrativets huvudsakliga argument blev mer och mer begripliga och därmed legitima för majoriteten av föräldrarna. En legitimitet som ytterligare förstärktes genom föräldrarnas egna erfarenheter av den nya skolorganisationen. Barnens upplevelser av de nya skolorna framhålls från rektorer och den intervjuade föräldern vara av särskild vikt:

Sen tror jag, kanske naivt, att det har betydelse att barnen träffar varandra. De kommer hem och pratar om varandra. Föräldrarna är ju också på besök ibland i skolan, och de ser ju barnen i klassrummet. Då blir det inte, det är de där somalierna eller syrierna, utan det blir Karida eller det blir Mohammed. Man blir en individ och inte en grupp (Rektor, Västerskolan).

Avslutningsvis ska påpekas att samtliga av de intervjuade policyaktörerna menar att projektet bara är i sin linda. Framtiden handlar om att utveckla organisation och pedagogisk verksamhet på skolorna och framförallt ha tålamod och uthållighet $\mathrm{i}$ arbetet med att genomföra projektet med styrd skolintegration.

\section{DISKUSSION}

Resultaten indikerar att skolintegrationspolicyn startade på gräsrotsnivå och att det förenande narrativ som artikulerar att skolsegregation förhindrar kommunens och de enskilda skolornas möjligheter att uppfylla skolans uppdrag om likvärdig måluppfyllelse och demokratiska medborgarfostran (jfr Englund, 2018) samt att styrd skolintegration är den bästa lösningen på dessa tillkortakommanden. För att förtydliga. Policyaktörernas tolkning är att stark skolsegregation och dess särhållande av olika sociala och etniska grupper omöjliggör uppfyllande av den svenska skollagen. Iscensättande av social interaktion mellan barn med skilda uppväxtvillkor och etniciteter i låg- och 
mellanstadieåldern och ansamling av lärarresurs vid skolenheterna kommer, menar de, inte bara förbättra likvärdigheten i måluppfyllelse. Integrerade skolor antas även motverka fördomar, öka förståelsen för den andre och bygga gemensamma värden och normer som delas av både minoritets- och majoritetsbefolkningen.

Omorganisationen handlar alltså om något större och vidare än kunskapsfrågan (elevers möjligheter till likvärdig måluppfyllelse). Det handlar i min tolkning om skolans medierade roll i samhället och hur denna ska vara en del i utvecklandet av social sammanhållning och inkorporering till ett gemensamt samhälleligt "vi" (jfr Alexander \& Tognato, 2019). Policyaktörernas artikulation av narrativet om en integrerad skola fusioneras implicit eller explicit med tanken om människors lika värde, en skola för alla och utvecklandet av en principiellt hållen solidaritet. Den lösning som policyaktörerna förespråkar kan förstås genom Alexanders (2006) begrepp mångkulturell inkorporering. Mångkulturell inkorporering förutsätter intersubjektiva lärandeprocesser: "This idea of a more symmetrical bargain implies mutual learning. It is not only the incoming group that changes, but the morals and manners of core groups" (Alexander, 2013, s. 532). Policyaktörernas bedömning är att detta gemensamma lärande bäst lăter sig göras $i$ yngre åldrar.

Vidare visar intervjuerna att detta narrativ formas dels genom pragmatiska ställningstaganden: "Vi kommer aldrig att bli en bättre skolkommun om vi inte gör någonting", dels mot djupt liggande värden, känslor och uppfattningar. För det första har narrativet en historisk förankring i den moderna enhetsskolans ambition om att verka för en skola för alla. Grundskoleutbildning ska bedrivas under likvärdiga villkor och ge utrymme för social mobilitet (jfr Isling, 1980). För det andra har narrativet också en tydlig relation till den svenska skollagen och dess påpekande om att verka för att alla barn ska ges likvärdiga möjligheter till personlig kunskapsutveckling, motverka fördomar och intolerans samt utveckla elevernas förståelse för samhällets kulturella mångfald (SFS 2010:800). Narrativet artikulerar för det tredje en stark tro på att möten mellan olika grupper kommer att reducera fördomar och överskrida etniska och sociala gränser mellan olika grupper i samhället. I ljuset av detta, argumenterar policyaktörerna för att det bara finns ett alternativ. Styrd skolintegration i syfte om att skapa en socialt och etniskt integrerad skola.

Narrativet för en integrerad skola kan alltså även förstås och förklaras genom policyaktörernas tro på den så kallade "kontakt-hypotesen" (Warrikoo, 2010; 2011). Den hypotes som utgår från att unga genom social interaktion över etniska och klassbundna gränser minskar fördomar och ökar solidariteten för den "andre" (Allport, 1979). Forskningen visar dock motstridiga resultat i detta avseende. Emot denna hypotes kan vi ställa Putnams (2007) konflikthypotes som argumenterar för att etniskt blandande 
bostadsområden eller institutioner minskar tilliten och den sociala sammanhållningen mellan olika grupper. Reay m.fl. (2011) framhåller exempelvis att det är sociologiskt naivt att tänka sig att "social mixing" i skola och undervisning skulle leda till ökad social sammanhållning. Dessa forskare menar alltså att "kontakt-hypotesen" bygger på förgivettagna övertygelser.

Annan empirisk forskning har dock visat att integrerade skolor gynnar samtliga elever, både vad gäller deras skolframgång, framtida livschanser och överskridanden av symboliska gränser mellan olika etniska grupper (Roda \& Stuart Wells, 2013; Wigerfelt, 2010; Warikoo, 2011; Johnson, 2011). I sin kunskapsöversikt kring vad som påverkar elevers studieresultat visar Skolverket (2009) att "kamrateffekten" har en väsentlig betydelse för elevernas skolframgång. Caldas och Bankston (1997) har bland annat visat att "kamrateffekten" är nästan lika stark för skolframgång som barnens sociala bakgrund. Eleverna själva och deras lärare förklarar att denna förändring skett på grund av att de fått fler studiemotiverade vänner (jfr Lund \& Lund, 2016). Pérez-Izaguirre (2018) och Lund (2019) har vidare pekat på att etniskt mixade skolor kan förändra ungas sätt att tänka och agera i relation till "den andre", men att dessa processer inte sker per automatik. Integrerade skolor är alltså, som Orfield och Lee (2006) framhåller, en nödvändig men inte tillräcklig åtgärd. För att dessa gränser ska överskridas krävs bland annat att skolan och dess pedagoger arbetar för att olikhet uppfattas som en tillgång (Lund \& Lund, 2016) och att olika elevgrupper genom social interaktion ges möjlighet att reflektera över och förhandla symboliska gränser mellan "vi" och "dem" (Lund 2019).

Det är dock, som aviserats i inledningen på denna artikel och av policyaktörerna själva, för tidigt att uttala sig om kontakthypotesen eller konflikthypotesen har rätt eller fel i sina utgångspunkter. Min analys och diskussion handlar inte om utfallet av dessa motstridiga utgångspunkter. Poängen är att policyaktörerna genom sitt sätt att argumentera och framträda med utgångspunkt i skollagens övergripande premisser, "återuppväckt" en meningsstruktur från enhetsskolans framväxt och den allmänt förankrade tanken om en likvärdig och medborgarbildande skola för alla. Genom att binda upp narrativets bärande argument på en sådan moraliskt motiverad meningsstruktur kan policyaktörerna inte bara skapa legitimitet inåt mot den egna verksamheten eller fusioneras utåt med föräldrar och lokalsamhällets känslostyrda respons på omorganisationen, utan framförallt internt förenas i en tro på att detta är rätt väg att gå. En förvissning som intellektuellt, rationellt och i hjärta och mage samlar policyaktörerna till handling.

Resultatpresentationen har också visat att detta narrativ i sig självt inte har kunnat åstadkomma förändring. Det är inte enbart en stark och kollektivt förenande narrativ bland policyaktörerna som skapat förutsättningar för initiering och genomförandet av en integrerad skola. Som jag har visat understöds narrativet av: (i) strukturella omständigheter - centralortens storlek, de 
korta avstånden mellan grundskolorna, befintliga skolbyggnaders arkitektoniska utformning och låg konkurrens mellan skolor i regionen har bidragit till omorganisationens utformning. Den begränsade konkurrensen och därmed bristen på "bättre utbildningsalternativ" inom den lokala skolmarknaden har förhindrat att medelklassföräldrar söker sig bort från de etniskt heterogena skolorna (jfr Kornvall \& Bender, 2018). (ii) kulturellt förankrad övertygelse - entreprenörsanda och regionens långa historia av arbetskraftsinvandring har skapat en "vana" i lokalsamhälle och skola om att inkorporera nyanlända och deras barn. En vana som ackompanjerats av känslor och förvissning om att olikhet är berikande för utvecklingen av kulturell och ekonomisk tillväxt. (iii) kollektivt aktörskap - rektorsgruppen uppmärksammar frågan om skolsegregationens negativa effekter för likvärdighet och samhällelig inkorporering. Gräsrotsinitiativet förankras i kommunpolitiken där ledamöterna i BUN oberoende av partitillhörighet och mandatfördelning har kommit att driva och förfina narrativets grundargument som de också har förmått förankra i den egna partiorganisationen. Implementeringen av omorganisationen bygger på en tydlig strategi, där timing och en transparent och uthållig kommunikation inåt mot lärarkåren och utåt mot föräldrar, har klarat av att vända rädslor, ilska och invändningar till tillit och förtroende.

Sammanfattningsvis har jag i denna artikel visat att narrativet för en integrerad skolan hämtar sina argument från skollag och en historiskt förankrad föreställning om den centrala betydelsen av likvärdighet samt att skola och utbildning har en medierande roll att fylla för ungas samhälleliga inkorporering. Detta narrativ understöds i sin tur av strukturella villkor, historiskt och kulturellt förenande meningssystem samt engagerade policyaktörers förmåga att överskrida meningsskillnader (jfr Alexander, 2011). Detta är i min tolkning centralt för att omstruktureringen av kommunens F6 verksamhet har kunnat genomföras. Huvudresultatet visar att policyambitionen om att skapa förändring genom styrd skolintegration kan ses som en form av kollektiv solidaritetshandling gentemot de barn som före omorganisationen genomförde sin skolgång $\mathrm{i}$ den lågpresterande och segregerade Österskolan. Det är genom policyaktörernas mod och enighet om att vidga: "the discourse of liberty" (Alexander, 2006: 551) som omstruktureringen kan förverkligas inom ramen för ett utbildningssystem som $i$ sin praktik driver utvecklingen $i$ annan riktning. 
${ }^{1}$ På grund av forskningsetiska skäl har jag valt att inte ange referens till denna utredning.

${ }^{2}$ Min anmärkning.

${ }^{3}$ Min anmärkning.

\section{REFERENSER}

Alba, Richard D., \& Holdaway, Jennifer (2013). The Children of Immigrants at School: A Comparative Look at Integration in the United States and Western Europe. New York University Press.

Alexander, Jeffrey. C. (2006). The Civil Sphere. Oxford University Press.

Alexander, Jeffrey. C. (2011). Performance and Power. Polity.

Alexander, Jeffrey. C. (2013). Struggling Over the Mode of Incorporation: Backlash Against Multiculturalism in Europe. Ethnic and Racial Studies, 36(4), 531-556.

Alexander, Jeffrey, \& Tognato, Carlos (red.) (2018). The Civil Sphere in Latin America. Cambridge University Press.

Allport, Gordon W. (1979). The Nature of Prejudice. Basic Books.

Ambrose, Anna (2016). Att navigera på en skolmarknad: en studie av skolvalfribetens geografi (Doktorsavhandling). Stockholms universitet.

Ambrose, Anna (2020). To Belong or Not? I Stefan Lund (Red.), Immigrant Incorporation, Education and the Boundaries of Belonging (s. 41-6). Palgrave Pivot.

Bifulco, Robert, Ladd, Helen F., \& Ross, Stephen L. (2009). Public School Choice and Integration: Evidence from Durham, North Carolina. Social Science Research: A Quarterly Journal of Social Science Methodology and Quantitative Research, 38(1), 71-85.

Billings, Stephen B., Deming, David J., \& Rockoff, Jonah (2013). School segregation, educational attainment, and crime: evidence from the end of bussing in Charlotte-Mecklenburg. The Quarterly Journal of Economics, 129(1), 435-476.

Brummet, Quentin (2014). The effect on school closings on students' achievements. Journal of public economics, 119(C), 108-124.

Bunar, Nihad, \& Sernhede, Owe. (Red.) (2013). Skolan och Ojämlikhetens Urbana Geografi. Om Skolan, Staden och Valfribeten. Daidalos.

Bunar, Nihad, \& Ambrose, Anna (2016). Schools, Choice and Reputation: Local School Markets and the Distribution of Symbolic Capital in Segregated Cities. Research in Comparative and International Education, 11(1), 34-51.

Caldas, Stephen J., \& Bankston, Carl L. (1997). Effect of school population socioeconomic status on individual academic achievement. The Journal of Educational Research, 90, 269-277.

Coleman, James S., Kelly, Sara D., \& Moore, John A. (1975). Trends in school segregation. The urban institute. 
Dagens Nyheter (2018). Skolsegregationen fortsätter öka. Tillgänglig: https://www.dn.se/nyheter/sverige/skolsegregationen-fortsatter-oka/

Dagens Nyheter (2020). Kötid ska inte längre få användas för urval till skolan. Tillgänglig: https://www.dn.se/debatt/kotid-ska-inte-langre-fa-anvandas-for-urval-tillskolan/

Dahlstedt, Magnus (red.) (2018). Förortsdrömmar: Ungdomar, utanförskap och viljan till inkludering. Linköping Studies in Social Work and Welfare 2018:3.

Danns, Dionne (2014). Desegregating Chicago's Public Schools: Policy Implementation, Politics, and Protest, 1965-1985. Palgrave Macmillan.

Delmont, Matthew F. (2016). Why bussing failed: race, media, and the national resistance to school desegregation. University of California press.

Dovemark, Marianne, \& Beach, Dennis (2016) From Learning to Labour to Learning for Precarity, Ethnography and Education, 11(2), 174-188.

Dovemark, Marianne, \& Holm, Ann-Sofie (2017). Pedagogic identities for sale. Segregation and homogenization in Swedish upper secondary school. British Journal of Sociology of Education, 38(4), 518-532.

Englund, Tomas (2018). Essä: Är demokratin hotad? Om privata intressen och skolans omvandling. Utbildning \& Demokrati, 27(1), 115-135.

Hansen, Kajsa Yang, \& Gustavsson, Jan-Erik (2016). Causes of educational segregation in Sweden: school choice or residential segregation. Educational Research and Evaluation, 22(1-2), 23-44.

Holm, Ann-Sofie, \& Dovemark, Marianne (2020). School Choice, We-Ness and School Culture. I Stefan Lund (Red.), Immigrant Incorporation, Education and the Boundaries of Belonging (s. 17-40). Palgrave Pivot.

Isling, Åke (1980). Kampen för och emot en demokratisk skola. Del 1. Sambällsstruktur och skolorganisation. Sober förlag.

Izquierdo, Honorio Martín, \& Minguez, Almudena Minguez (2003). Sociological theory of education in the dialectical perspective. I Carlos Alberto Torres, \& Ari Antikainen (Red.), The international handbook on the sociology of education. An international assessment of new research and theory (s. 21-41). Rowman \& Littlefield.

Jessee, Erin (2018). The Life History Interview. I Pranee Liamputtong (Red.), Handbook of Research Methods in Health Social Sciences (s. 425-441). Springer.

Johnson, Rucker C. (2011). Long-run impacts of school desegregation \& school quality on adult attainments. Working paper 16664. http://www.nber.org/papers/w16664

Jämte, Jan, Arneback, Emma, Berg, Andreas, \& Trumberg, Anders (2021). En skola i integration: lärdomar från Örebros arbete med styrd skolintegration. Örebro universitet.

Kallstenius, Jenny (2010). De mångkulturella innerstadsskolorna: Om skolval, segregation och utbildningsstrategier i Stockholm (Doktorsavhandling). Acta Universitatis Stockholminesis. 
Kornvall, Per, \& Bender, German (2018). Ett söndrat land: Skolval och segregation $i$ Sverige. Arena idé.

Kvale, Steinar (1997). Den kvalitativa forskningsintervjun. Studentlitteratur.

Larsson-Taghizadeh (2020). Are students in receiving schools hurt by the closing of low-Performing schools? Effects of school closures on receiving schools in Sweden 2000-2016. Economics of Education Review, 78(C).

Lamont, Michele, \& Molnár, Virag (2002). The Study of Boundaries in the Social Sciences. Annual Review of Sociology, 28, 167-195.

Lund, Stefan (2015). School choice, Ethnic Divisions and Symbolic Boundaries. Palgrave Pivot.

Lund, Stefan (2019). Immigrant incorporation in Education: High school students' negotiation of belonging. I Jeffrey C. Alexander, Anna Lund, \& Andrea Voyer (Red.), The Nordic Civil sphere (s. 203-228). Polity.

Lund, Stefan (Red.) (2020). Immigrant incorporation, education and the boundaries of belonging. Palgrave Pivot.

Lund, Anna, \& Lund, Stefan (Red.) (2016). Skolframgång i det mångkulturella sambället. Studentlitteratur.

Malmberg, Bo, \& Andersson Eva K. (2020). Do schools mix students from different neighbourboods? School segregation and student allocation in Swedish municipalities. Stockholm Research Reports in Demography, 2019:07.

Mella, Orlando, \& Palm, Irving (2007). Mångfaldsbarometern 2007. Uppsala universitet.

Nilsson, Henrik (2015). Kultur och utbildning: en tolkning av två grundskolors mångkulturella kontexter (Doktorsavhandling). Linnaeus University Press.

OECD. (2015). Improving Schools in Sweden: An OECD Perspective. OECD. Tillgänglig: http://www.oecd.org/education/school/Improving-Schools-in-Sweden.pdf

Orfield, Gary, \& Lee, Chungmei (2006). Racial Transformation and the Changing Nature of Segregation. The Civil Rights Project at Harvard University. Harvard University.

Osman, Ali, \& Månsson, Niclas (2015). I go to Teachers Conferences, but I do Not Understand What the teacher is saying": Somali Parents 'Perception of the Swedish School. International Journal of Multicultural Education, 17(2), 36-52

Ozga, Jenny (2000). Policy research in educational settings: contested terrain. Open University Press.

Pérez-Izaguirre, Elizabeth (2018). 'No, I Don't Like the Basque Language.' Considering the Role of Cultural Capital within Boundary-Work in Basque Education. Social sciences, MDPI, 7(9), 1-20.

Putnam Robert D. (2007). E Pluribus Unum: Diversity and Community in the Twenty-first Century. Scandinavian Political Studies, 30(2), 137-174. 
Reay, Diane, Crozier, Gill, \& James, David (2011). White Middle-Class Identities and Urban Schooling. Palgrave Macmillan.

Riessman, Catherine Kohler (2008). Narrative Methods for the Human Sciences. Sage.

Roda, Allison, \& Stuart Wells, Amy (2013). School Choice Policies and Racial Segregation: Where White Parents' Good Intentions, Anxiety, and Privilege Collide. American Journal of Education, 119(2), 261-293.

Sjöstrand Öhrfelt, Magdalena (2019). Ord och inga visor konstruktioner av förskolebarnet $i$ kunskapsekonomin (Doktorsavhandling). Linnaeus University Press.

Skollagen (SFS 2010:800). Regeringskansliet. Tillgänglig: https://www.riksdagen.se/sv/dokument-lagar/dokument/svenskforfattningssamling/skollag-2010800_sfs-2010-800.

Skolverket, (2009). Skolverkets bild av utvecklingen av kunskapsresultaten i grundskolan och av elevers studiemiljö. Fritzes.

SOU 2020:28 En mer likvärdig skola: minskad skolsegregation och förbättrad resurstilldelning. Utbildningsdepartementet. Tillgänglig: https://www.regeringen.se/498b68/contentassets/fcf0e59defe04870a39239f5bda $331 \mathrm{f} 4 /$ en-mer-likvardig-skola--minskad-skolsegregation-och-forbattradresurstilldelning-sou-202028

Svenska Dagbladet (2018). Hans Bergström: För skolverket betyder det inget vad skolan gör. Tillgänglig: https://www.svd.se/hans-bergstrom-for-skolverket-betyder-det-ingetvad-skolan-gor

Voyer, Andrea (2018). 'If the students don't come, or if they don't finish, we don't get the money.' Principals, immigration, and the organisational logic of school choice in Sweden. Ethnography and Education, 14(4), 448-464.

Warikoo, Natasha Kumar (2010). Symbolic boundaries and school structure in New York and London schools. American Journal of Education, 116(3), 423-451.

Warikko, Natasha Kumar (2011). Balancing Acts: Youth Culture in the Global City. University of California Press.

Wigerfelt, Berit (2010). Kroksbäck möter Linné: en utvärdering av integration mellan två skolor i Malmö. Malmö stad. 